\title{
KEEFEKIFAN TEKNIK DIE DAN TEKNIK OBJEK LANGSUNG DALAM KETERAMPILAN BERCERITA DENGAN ALAT PERAGA
}

\author{
Sawacu Pragina \\ STKIP Qamatus Huda, Lombok Tengah, NTB \\ email: ginatangkul@gmail.com
}

\begin{abstract}
ABSTRAK
Penelitian ini memiliki tiga tujuan yaitu; (1) mengidentifikasi apakah teknik DIE lebih efektif daripada teknik Konvensional; (2) apakah teknik Objek Langsung lebih efektif daripada teknik Konvensional; (3) manakah teknik yang lebih efektif diantara teknik DIE dan teknik Objek Langsung dalam keterampilan bercerita dengan alat peraga pada siswa kelas VII SMP Plus Munirul Arifin NW Praya Kabupaten Lombok Tengah. Penelitian ini merupakan quasi experiment dengan randomized pretest-posttest control group design. Hasil penelitian menunjukkan (1) teknik DIE lebih efektif daripada teknik Konvensional dalam keterampilan bercerita dengan alat peraga pada siswa kelas VII SMP Plus Munirul Arifin Praya Kabupaten Lombok Tengah dengan mean difference sebesar 12,14286 dan nilai $\mathrm{p} \leq 0,05$; (2) teknik Objek Langsung lebih efektif daripada teknik Konvensional dalam pembelajaran bercerita dengan alat peraga pada siswa kelas VII SMP Plus Munirul Arifin Praya Kabupaten Lombok Tengah dengan mean difference sebesar 5,91429 dan nilai sig. $0,030 \leq 0,05$; (3) teknik DIE lebih efektif daripada teknik Objek Langsung dalam pembelajaran bercerita dengan alat peraga pada siswa kelas VII SMP Plus Munirul Arifin Praya Kabupaten Lombok Tengah dengan mean difference sebesar 6,22857 dan nilai sig. sebesar $0,021 \leq 0,05$. Berdasarkan hasil penelitian tersebut, teknik DIE adalah teknik yang paling efektif.
\end{abstract}

Kata Kunci: teknik DIE, teknik objek langsung

\section{THE EFFECTIVENESS OF DIE TECHNIQUE AND DIRECT-OBJECT TECHNIQUE IN STORYTELLING SKILLS USING REALIA}

\begin{abstract}
This research was aimed at identifying: (1) whether DIE technique is more effective than conventional technique, (2) whether direct-object technique is more effective than conventional technique and (3) which is more effective between DIE technique and direct-object technique in story-telling skills using realia at Grade VII Students in SMP Plus Munirul Arifin NW Praya. This study was a quasi-experimental research using PretestPosttest Control Group Design. The finding revealed that (1) DIE technique is more effective than conventional technique in story-telling skills using realia at Grade VII students in SMP Plus Munirul Arifin NW Praya indicated by the mean difference: 12.14286 and pvalue: $\leq 0.05,(2)$ direct-object technique is more effective than conventional technique in story-telling skills using realia at Grade VII students in SMP Plus Munirul Arifin NW Praya indicated by the mean difference: 5.91429 and sig. value: $0.030 \leq 0.05$, (3) DIE technique is more effective than direct-object technique in story-telling skills using realia at Grade VII students in SMP Plus Munirul Arifin NW Praya indicated by the mean difference: 6.22857 and sig. value: $0.021 \leq 0.05$. Based on the research findings, DIE technique is the most effective technique.
\end{abstract}

Keywords: DIE technique, direct object technique 


\section{PENDAHULUAN}

Dalam kehidupan bermasyarakat, setiap orang berhubungan dengan orang lain melalui bahasa. Bahasa merupakan kegiatan yang penting karena merupakan bagian dari kehidupan kita (Thomas\&Wareing, 2007: 26). Bahasa merupakan dasar untuk menyampaikan sesuatu kepada orang lain baik secara lisan maupun tertulis. Salah satu aspek kebahasaan yang membantu seseorang menyampaikan ide, pendapat, gagasan, maupun pikirannya secara lisan kepada orang lain adalah keterampilan berbicara. Keterampilan berbicara dalam pembelajaran di sekolah harus dikuasai oleh siswa karena mampu menunjukkan kemampuan komunikatif yang dimiliki oleh siswa itu sendiri. Selain itu, (Nurgiyantoro, 2013: 397) menyebut bahwa kemampuan berbicara merupakan keterampilan yang bersifat produktif. Bersifat produktif artinya adalah dalam kegiatan berbicara seperti mengungkapkan pandangan, pikiran, pendapat atau gagasan mengenai suatu masalah, siswa akan melibatkan pikiran, kesiapan mental, keberanian, dan perkataan yang jelas sehingga dapat dipahami oleh orang lain.

Musfiroh (2008: 87) juga mengungkapkan bahwa memacu kemampuan berbicara seorang anak merupakan hal yang penting. Salah satu keterampilan berbicara yang juga aktif dalam memproduksi ide yaitu keterampilan bercerita dengan alat peraga. Kemampuan bercerita dengan alat peraga menurut Morrow dalam (Tompkins, 1995:129) merupakan kemampuan yang mampu meningkatkan imaginasi anak, meningkatkan kemampuan bahasa, membantu anak menilai karakter tokoh dalam cerita dan membantu anak mengembangkan penilaian terhadap suatu cerita. Berdasarkan beberapa pendapat tersebut, ditarik kesimpulan bahwa keterampilan bercerita khususnya dengan alat peraga mampu memberikan manfaat untuk perkembangan anak terutama dalam kemampuan linguistik maupun paralinguistik.

Hasil Prasurvei yang dilakukan pada siswa dan guru pada kelas VII di SMP Plus Munirul Arifin NW Praya Kabupaten Lombok Tengah pada proses pembelajaran menunjukkan bahwa siswa kelas VII pada SMP tersebut belum sepenuhnya mendapatkan stimulasi yang tepat dalam bercerita dengan alat peraga.
Akibat dari hal tersebut, penggunaan alat peraga dalam bercerita tidak digunakan secara optimal oleh siswa. Hal tersebut akhirnya berpengaruh terhadap perkembangan imaginasi, kemampuan linguistik maupun paralinguistik yang dimiliki siswa. Selain itu, hasil prasurvei pada lingkungan sekolah juga menunjukkan penggunaan ketepatan bahasa kurang baik, mengingat bahwa dialek bahasa Suku Sasak asli masih kental dan penyerapan bahasa daerah maupun bahasa asing dalam penggunaan bahasa Indonesia masih sering terjadi. Penyerapan bahasa asing terutama bahasa Inggris menjadi biasa di lingkungan sekolah tersebut karena dalam lingkungan sekolah, bahasa Inggris menjadi bahasa komunikasi yang harus digunakan oleh seluruh siswa. Berdasarkan fenomena itulah guru harus memilih dan menggunakan teknik pembelajaran yang menarik dan mampu membangun imaginasi siswa dengan memberikan stimulasi pada siswa khususnya dalam keterampilan bercerita dengan alat peraga. Teknik DIE dan teknik Objek Langsung dalam penelitian ini diduga mampu meningkatkan keterampilan bercerita dengan alat peraga pada siswa kelas VII SMP Plus Munirul Arifin NW Praya Kabupaten Lombok Tengah.

Teknik DIE diduga mampu memberikan kesempatan kepada siswa secara lebih luas untuk mengungkapkan konsep, gagasan maupun informasi yang mereka dapatkan dari gambar melalui kegiatan bercerita dengan alat peraga. Teknik DIE adalah teknik yang menggunakan bentuk visual seperti gambar-gambar suatu peristiwa atau kegiatan dengan tujuan agar siswa mampu membedakan, menjelaskan dan menafsirkan suatu informasi, konsep, bahkan gagasan dari bentuk-bentuk visual yang diberikan serta siswa mampu menerapkan hal tersebut dalam kegiatan pembelajaran (Sudjana, 2001). Teknik kedua adalah teknik pembelajaran Objek Langsung yang merupakan salah satu teknik pembelajaran kontekstual komponen pemodelan. Teknik Objek Langsung dapat memberikan stimulasi pada siswa dalam meningkatkan keterampilan berbahasa yang dimiliki. Keterampilan berbahasa yang dimiliki siswa berkaitan dengan keterampilan berbicara. Melalui pembelajaran konteksual, proses belajar diharapkan berlangsung alamiah (Nurhadi, 2009: 4). Berlangsung secara alamiah berbentuk seperti kegiatan siswa 
bekerja dan mengalami, bukan transfer pengetahuan dari guru ke siswa. Strategi pembelajaran lebih dipentingkan daripada hasil belajar. Hasil pembelajaran lebih bermakna bagi anak untuk memecahkan persoalan, berpikir kritis, dan melaksanakan observasi serta menarik kesimpulan. Melalui teknik atau model pengamatan langsung, proses belajar siswa akan berlangsung secara alamiah khususnya dalam bercerita dengan alat peraga. Proses tersebut menjadi alamiah karena siswa mengalami langsung kegiatan pembelajaran yaitu siswa mengamati langsung objek yang dimodelkan baik di dalam maupun di luar kelas. Berdasarkan proses pembelajaran tersebut, siswa akhirnya melakukan observasi langsung pada objek tersebut kemudian berpikir secara kritis untuk mengambil kesimpulan dalam menyusun pokok-pokok cerita yang akan di susun menjadi sebuat cerita yang menarik.

Teknik Objek Langsung juga salah satu teknik yang terbukti baik dalam keterampilan menulis. Teknik pembelajaran menulis Objek Langsung bertujuan agar siswa dapat menulis dengan cepat berdasarkan objek yang dilihat (Suyatno, 2004: 82). Teknik Objek Langsung diduga mampu menjadi stimulasi yang efektif dalam meningkatkan keterampilan bercerita dengan alat peraga siswa kelas VII SMP Plus Munirul Arifin NW Praya Kabupaten Lombok Tengah. Hal tersebut karena objek yang dilihat siswa lebih kongkrit, nyata, dapat diraba bahkan dapat dirasakan. Kedua teknik tersebut diharapkan dapat menjadi teknik yang efektif dalam proses pembelajaran keterampilan bercerita dengan alat peraga pada siswa kelas VII SMP Plus Munirul Arifin NW Praya Kabupaten Lombok Tengah.

Berdasarkan latar belakang tersebut, dapat dibuat rumusan masalah dalam penelitian ini yaitu; (1) perbedaan keefektifan antara penggunaan teknik DIE dan teknik konvensional dalam keterampilan bercerita dengan alat peraga pada siswa kelas VII SMP Plus Munirul Arifin NW Praya Kabupaten Lombok Tengah; (2) perbedaan keefektifan antara penggunaan teknik Objek Langsung dan teknik konvensional dalam keterampilan bercerita dengan alat peraga pada siswa kelas VII SMP Plus Munirul Arifin NW Praya Kabupaten Lombok Tengah; (3) efektivitas teknik DIE dan teknik objek langsung dalam keterampilan bercerita dengan alat peraga pada siswa kelas VII SMP Plus Munirul Arifin NW Praya Kabupaten Lombok Tengah.

Berdasarkan rumusan masalah, tujuan penelitian yaitu : (1) mengidentifikasi perbedaan keefektifan penggunaan teknik DIE dan teknik Konvensional dalam keterampilan bercerita dengan alat peraga pada siswa kelas VII SMP Plus Munirul Arifin Praya Kabupaten Lombok Tengah; (2) mengidentifikasi perbedaan keeektifan penggunaan teknik objek langsung dan teknik Konvensional dalam keterampilan bercerita dengan alat peraga pada siswa kelas VII SMP Plus Munirul Arifin Praya Kabupaten Lombok Tengah; (3) mengidentifikasi perbedaan keefektifan penggunaan teknik DIE dan teknik Objek Langsung dalam keterampilan bercerita dengan alat peraga pada siswa kelas VII SMP Plus Munirul Arifin Praya Kabupaten Lombok Tengah.

\section{METODE}

Penelitian ini menggunakan metode kuantitatif. Jenis penelitian yang digunakan adalah penelitian eksperimen yaitu quasi eksperiment dengan desain penelitian randomized Pretest-Posstest Control Group Design. Penelitian ini mengambil tempat di SMP Plus Munirul Arifin NW Praya yang terletak di Kabupaten Lombok Tengah, Provinsi Nusa Tenggara Barat pada bulan Februari s.d Mei 2016.

Pada desain penelitian ini, terdapat 3 kelompok yang dipilih secara acak, yaitu 2 kelompok eksperimen dan 1 kelompok kontrol yang masing-masing diberi tes awal dan tes akhir. Pada kelompok eksperimen diberikan perlakuan dengan teknik DIE dan teknik objek langsung, sedangkan untuk kelompok kontrol juga diberi perlakuan selain perlakuan yang diberikan pada kelompok eksperimen yaitu menggunakan teknik konvensional. Desain penelitian dapat dilihat di bawah ini:

$\begin{array}{lllll}\mathrm{E}_{1} & (\mathrm{R}) & \mathrm{O}_{1} & \mathrm{X} 1 & \mathrm{O}_{2} \\ \mathrm{E}_{2} & (\mathrm{R}) & \mathrm{O}_{3} & \mathrm{X}_{2} & \mathrm{O}_{4} \\ \mathrm{~K} & (\mathrm{R}) & \mathrm{O}_{5} & - & \mathrm{O}_{6}\end{array}$

Desain eksperimental tersebut menggambarkan bahwa terdapat 3 kelompok sampel. 2 kelompok bertindak sebagai kelompok eks- 
perimental dan 1 kelompok sebagai kelompok kontrol. Kelompok eksperimental dan kelompok kontrol diberikan tes awal (pretest) keterampilan bercerita dengan alat peraga, kemudian dilakukan uji perbedaan kemampuan bercerita dengan alat peraga antara ketiganya untuk memperoleh kondisi awal yang sama. Pada akhir perlakuan dilihat perbedaan pencapaian pretest dan posttest kelompok eksperimen $\left(\mathrm{O}_{1} \square \mathrm{O}_{2}\right.$ dan $\mathrm{O}_{3} \square$ $\mathrm{O}_{4}$ ) dan perbedaan pretest posttest pada kelompok kontrol $\left(\mathrm{O}_{5} \square \mathrm{O}_{6}\right)$. Selanjutnya postes kelompok eksperimen yang diberi perlakuan dengan teknik DIE dan teknik Objek Langsung dibandingkan dengan posttest kelompok kontrol atau kelompok dengan teknik konvensional $\left(\mathrm{O}_{2}\right.$ $\square \mathrm{O}_{4} \square \mathrm{O}_{6}$ ).

Langkah-langkah yang dilakukan dalam penelitian ini adalah: (1) melakukan prasurvei dan mengajukan perizinan ke sekolah; (2) pembuatan instrument dan uji coba instrument; (3) mengadakan pertemuan koordinasi dengan guru dilanjutkan dengan pembekalan mengenai pembelajaran keterampilan becerita dengan alat peragamenggunakan dua teknik yaitu teknik DIE dan teknik Objek Langsung; (4) mengembangkan strategi pembelajaran bersama dengan guru pada kelompok eksperimen; (5) menentukan kelompok eksperimen dan kontrol secara random; (6) menentukan sampel penelitian dalam setiap kelompok secara random; (7) melaksanakan Pretest dilanjutkan dengan eksperimen; (8) melakukan Posttest setelah eksperimen selesai, dan (9) analisis data.

Penelitian ini mengambil tempat di SMP Plus Munirul Arifin NW Praya yang terletak di Kabupaten Lombok Tengah, provinsi Nusa Tenggara Barat pada bulan Februari s.d Mei 2016. Alasan pemilihan sekolah tersebut sebagai tempat penelitian karena SMP Plus Munirul Arifin NW Praya masih menerapkan Kurikulum Tingkat Satuan Pendidikan (KTSP) dan merupakan salah satu sekolah swasta yang sedang berkembang baik jika dibandingkan dengan SMP swasta yang lain. Alasan selanjutnya yaitu dari hasil pra-survei, sekolah tersebut belum secara penuh menggunakan teknik pembelajaran yang menarik dan memacu siswa untuk lebih kreatif dalam proses pembelajaran, terutama untuk pelajaran Bahasa Indonesia dalam keterampilan berbicara yaitu bercerita dengan alat peraga.

Populasi dalam penelitian ini adalah seluruh siswa kelas VII SMP Plus Munirul Arifin NW Praya Kabupaten Lombok Tengah tahun pelajaran 2015/2016. Siswa terdiri dari 5 kelas dengan jumlah 202 orang siswa. Sampel penelitian ditentukan melalui teknik cluster random sampling. Berdasarkan teknik sampel tersebut, diambil sampel penelitian yang berjumlah 105 siswa. Perincian siswa kelas VII SMP Plus Munirul Arifin NW Praya Lombok Tengah dapat dilihat pada tabel 1 dibawah ini.

Tabel 1. Jumlah Peserta Didik SMP Plus Munirul Arifin NW Praya Kabupaten Lombok Tengah

\begin{tabular}{clc}
\hline No & \multicolumn{1}{c}{ Kelas } & Jumlah siswa \\
\hline 1 & VII A & 39 \\
2 & VII B & 39 \\
3 & VII C & 38 \\
4 & VII D & 43 \\
5 & VII E & 43 \\
\hline & JUMLAH & 202 \\
\hline
\end{tabular}

Berdasarkan tabel 1, penentuan kelompok eksperimen dan kelompok kontro dilakukan dengan teknik simple cluster random sampling melalui undian yang dilakukan bersama dengan guru yang mengajar terhadap seluruh kelas VII SMP Plus Munirul Arifin NW Praya yang terdiri dari Kelompok VII A, B, C, D dan E. Hal ini dilakukan untuk menghindari subjektivitas peneliti, sehingga semua kelas mempunyai kesempatan yang sama sebagai sampel penelitian. Adapun hasil pemilihan kelompok secara random dapat dilihat pada tabel 2 di bawah ini:

Tabel 2. Perincian Sampel Penelitian Kelompok VII SMP Plus Munirul Arifin NW Praya Kabupaten Lombok Tengah. Tahun Pelajaran 2015/2016

\begin{tabular}{cccc}
\hline No & Kelas & $\begin{array}{c}\text { Jumlah } \\
\text { siswa }\end{array}$ & $\begin{array}{c}\text { Sampel } \\
\text { Penelitian }\end{array}$ \\
\hline 1 & VII A & 39 orang & 35 orang \\
2 & VII B & 39 orang & 35 orang \\
3 & VII C & 38 orang & 35 orang \\
& Jumlah & 116 orang & 105 orang \\
\hline
\end{tabular}

Hasil random diperoleh kelas VII 
B yang berjumlah 39 orang terpilih sebagai kelompok kontrol yang menggunakan teknik konvensional, kelas VII A yang berjumlah 39 orang terpilih sebagai kelompok eksperimen 1 yang menggunakan teknik DIE, dan kelas VII $\mathrm{C}$ yang berjumlah 38 orang sebagai kelompok eksperimen 2 yang menggunakan teknik Objek Langsung.

Siswa kelas VII A, B dan C yang berjumlah 116 orang tetap menerima perlakuan menggunakan teknik pembelajaran yang telah ditentukan. Kelas A dengan teknik DIE, kelas $\mathrm{C}$ dengan teknik objek langsung dan kelas B sebagai kelas kontrol yang menggunakan teknik selain yang dieksperimenkan yaitu teknik konvensional. Selain itu semua siswa tetap mengikuti evaluasi yang dilakukan pada setiap akhir pertemuan, sedangkan sampel penelitian yang berjumlah 105 orang siswa, dengan perincian dari 3 kelas pada masing-masing kelas hanya diambil 35 orang dari siswa yang aktif mengikuti setiap perlakuan selama dua belas kali secara acak, yaitu dengan mengacak siswa yang selalu hadir selama siswa menerima perlakuan dan siswa yang tidak pernah hadir selama perlakuan tidak ikut serta dalam pengambilan data sampel.

Teknik pengumpulan data dilakukan dengan tes (pretest dan posttest) dan nontes yang berupa pengamatan (lembar observasi). Observasi digolongkan menjadi dua, yakni observasi nonsistematis, yang dilakukan oleh peneliti tanpa menggunakan instrumen pengamatan, dan observasi sistematis, yang dilakukan peneliti dengan menggunakan pedoman sebagai instrumen pengamatan (Ismawati, 2009: 93). Pada penelitian ini yang digunakan adalah observasi sistematis atau berstruktur. Dalam observasi berstruktur, kegiatan pengamat telah diatur dan dibatasi dengan kerangka kerja tertentu yang telah disusun secara sistematis (Nurgiyantoro, 2013: 93). Observasi dilakukan ketika guru atau peneliti sedang menerapkan teknik Objek Langsung dan teknik DIE dalam kegiatan bercerita di dalam kelompok eksperimen. Lembar observasi ini digunakan sebagai pendukung penelitian agar mendapatkan data yang sesuai karena mendapatkan informasi dengan cara mengamati objek secara langsung, cermat dan terencana.
Berdasarkan rancangan penelitian, pengumpulan data tes unjuk kerja bercerita yang dilakukan dalam penelitian ini yaitu dengan Pretest (tes kemampuan awal) dilaksanakan 1 kali secara serempak sebelum diberikan perlakuan pada 2 kelas yang telah terpilih sebagai 2 kelompok eksperimen dan 1 kelas kontrol yang tetap juga diberi perlakuan selain perlakuan yang dieksperimenkan. Tes kemampuan bercerita awal dilakukan dengan meminta siswa bercerita berdasarkan tema yang telah ditentukan. Tes kemampuan bercerita akhir atau posttest juga dilaksanakan 1 kali secara serempak setelah 2 kelompok eksperimen diberi perlakuan dan posttest juga dilaksanakan pada 1 kelompok kontrol yang diberi perlakuan selain perlakuan yang dieksperimenkan. Berdasarkan hal tersebut, total pertemuan pada 3 Kelompok yang diberikan perlakuan masing-masing teknik sebanyak 36 kali tanpa mengikuti pertemuan prettes dan posttes.

Pengambilan data dalam penelitian ini menggunakan rubrik penilaian performansi atau unjuk kerja lisan keterampilan bercerita dengan alat peraga. Instrument tersebut dibuat menggunakan skala likert dengan 5 alternatif (5; sangat baik, 4;baik, 3;cukup baik, 2;kurang, dan 1; sangat kurang). Instrumen tersebut berdasarkan pada teori pedoman keterampilan bercerita berdasarkan rangsang gambar dan menceritakan kembali buku cerita dari Burhan Nurgiyantoro yang telah dimodifikasi. Adapun contoh rubrik penilaian yang dijadikan rujukan untuk membuat lembar penilaian terhadap performansi siswa dalam bercerita dengan alat peraga dapat dilihat pada tabel 3 dan tabel 4 .

Berdasarkan dua rujukan pada tabel 3 dan 4 , maka pembuatan rubrik penilaian tersebut perlu dimodifikasi dan disederhanakan. Modifikasi dilakukan dengan menyesuaikan silabus kelas VII SMP Plus Munirul Arifin NW Praya Lombok Tengah dalam bercerita dengan alat peraga. Selain itu, disesuaikan juga dengan masalah yang dihadapi siswa ketika pembelajaran keterampilan bercerita di dalam maupun di luar kelas. Bercerita dalam situasi seperti ini baik di dalam maupun di luar kelas, penuturan yang digunakan siswa tidak semata-mata ditentukan oleh ketepatan bahasa saja melainkan dibantu juga oleh unsur-unsur paralinguistik 
Tabel 3. Contoh Rubrik Penilaian Tugas Menceritakan kembali Buku Cerita

\begin{tabular}{llllll}
\hline \multirow{2}{*}{ No } & \multicolumn{1}{c}{ Aspek yang dinilai } & \multicolumn{4}{c}{ Tingkat Capaian Kinerja } \\
\cline { 3 - 5 } & \multicolumn{1}{c}{ Ketepatan isi cerita } & & & 4 & 5 \\
\hline 1 & Ketepatan penunjukan detil cerita & & & & \\
3 & Ketepatan logika cerita & & & \\
4 & Ketepatan makna keseluruhan cerita & & & \\
5 & Ketepatan kata & & & \\
6 & Ketepatan kalimat & & & \\
7 & Kelancaran & & & \\
\hline
\end{tabular}

Tabel 4. Contoh Rubrik Penilaian Berbicara Berdasarkan Rangsang Gambar

\begin{tabular}{llllll}
\hline \multirow{2}{*}{ No } & \multicolumn{1}{c}{ Aspek yang dinilai } & \multicolumn{4}{c}{ Tingkat Capaian Kinerja } \\
\cline { 3 - 5 } & \multicolumn{1}{c}{ Kesesuaian dengan gambar } & & & 3 & 4 \\
2 & Ketepatan logika urutan cerita & & & & \\
3 & Ketepatan makna keseluruhan cerita & & & \\
4 & Ketepatan kata & & & \\
5 & Ketepatan kalimat & & & \\
6 & Kelancaran & & & \\
\hline
\end{tabular}

seperti gerakan, ekspresi wajah, nada suara dan sebagainya. Berdasarkan hal tersebut, modifikasi rubrik penilaian dalam penelitian ini adalah dengan menyederhanakan serta mengombinasikan rubrik penilaian dengan berlandaskan pada faktor penunjang keefektifan berbicara baik yang berupa unsur linguistik maupun paralinguistik.

Pada kedua rujukan penilaian di atas, ketepatan kalimat yang ada pada no (6) dalam penilaian berdasarkan menceritakan kembali buku cerita dan ketepatan kalimat pada no (5) dalam penilaian berbicara berdasarkan rangsang gambar dimodifikasi menjadi struktur yang masuk dalam aspek penilaian ke (4) dalam penilaian bercerita dengan alat peraga. Aspek penilaian (4) struktur dalam penilaian bercerita dengan alat peraga mencakup penilaian yang mencakup penggunaan kalimat, frasa, dan kata. Aspek kata memang ada di dalam struktur namun untuk aspek ketepatan kata yang tetap ditulis dalam penilaian bercerita dengan alat peraga sebagai aspek penilaian ke (5) mencakup kriteria tentang bagaimana pemilihan kata yang digunakan, apakah sudah bervariasi atau tidak.
Modifikasi selanjutnya adalah pada aspek no (1) kesesuaian dengan gambar pada penilaian berbicara berdasarkan rangsang gambar dan aspek no (1) kesesuaian isi pembicaraan pada penilaian berbicara berdasarkan rangsang suara dimodifikasi menjadi (1) pelafalan, hal tersebut dikarenakan dalam bercerita dengan alat peraga siswa tidak menggunakan rangsang suara walaupun gambar memang dipakai pada salah satu teknik yaitu teknik DIE dalam kelompok kontrol pertama. Dalam pelafalan, kriteria yang dinilai mencakup pelafalan fonem dan ada atau tidak pengaruh pelafalan dari bahasa daerah atau bahasa asing. Modifikasi untuk aspek penilaian yang ke (3) ketepatan makna keseluruhan cerita yang ada pada penilaian berdasarkan gambar dan suara dirubah menjadi aspek penilaian ke (3) yaitu ketepatan logika isi cerita. Hal tersebut karena dalam ketepatan logika isi cerita, kriteria yang dinilai adalah bagaimana tokoh, latar, alur yang terkonsep jelas atau tidak yang dapat mewakili makna cerita tersebut.Pada aspek penilaian bercerita dengan alat peraga ini juga ditambahkan unsur paralinguistik seperti 
gerakan badan dan ekspresi wajah yang ada dalam aspek penialian no (2) yaitu ekspresi (mimik muka dan gerakan badan).

Teknik analisis data yang digunakan dalam penelitian ini adalah teknik statistik parametrik yaitu teknik Korelasi Pearson dimana nilai yang diperoleh untuk pretest dan posttest tersebut didapat dari dua rater yang akan digunakan utuk uji hubungan antar kedua rater. Selanjutnya dilanjutkan dengan teknik anova (analysis of variance) untuk mengetahui ada tidaknya perbedaan keefektifan antara kelompok eksperimen dengan kelompok kontrol kemudian dilanjutkan dengan uji Scheffe dan uji t untuk mengetahui seberapa besar perbedaan antara kelompok eksperimen dan kelompok kontrol. Ada dua bentuk pengujian sebelum analisis data dilakukan yaitu pengujian persyaratan analisis dan pengujian hipotesis. Analisis data dilakukan dengan SPSS veri 21. Terdapat tiga variabel yang akan dibandingkan dengan menggunakan perhitungan statistik tersebut yaitu teknik DIE, teknik Objek Langsung dan teknik Konvensional.

Berkaitan dengan uji prasyarat analisis yaitu normalitas, data yang dianalisis haruslah data yang berdistribusi normal. Normalitas digunakan untuk menguji data pretest dan posttest apakah memiliki sebaran normal atau tidak. Normalitas skor keterampilan bercerita yang berupa data pretest dan prettest dilakukan dengan menggunakan uji Lilliefors Significans Correlation dari kolmogrof Smirnof dengan taraf signifikansi $(\alpha=0,05)$ dengan menggunakan program aplikasi SPSS versi 21,0. Uji normalitas data ini bertujuan untuk mengetahui normal atau tidaknya distribusi populasi yang diteliti. Jika sig atau taraf signifikansi kurang dari 0,05 maka data tidak berdistribusi normal.
Sebaliknya, jika nilai signifikansi (sig) lebih dari 0,05 data tersebut berdistribusi normal.

Selanjutnya untuk uji prasyarat yang berkaitan dengan homogenitas, homogenitas varians ini untuk mengetahui apakah sampel yang diambil dari populasi memiliki signifikansi satu sama lain. Homogenitas digunakan untuk menguji kesamaan varian antara tiga kelompok yang dibandingkan. Penerimaan atau penolakan uji homogenies didasarkan pada: (1) jika nilai sig atau taraf signifikan kurang dari 0,05 maka ketiga varians populasi tidaklah homogen, dan (2) jika nilai sig atau taraf signifikansi lebih dari 0,05 maka ketiga varians populasi homogen.

\section{HASIL DAN PEMBAHASAN}

Pada pembahasan hasil penelitian ini, uji hipotesis pertama yaitu membandingkan keefektifan kelompok eksperimen 1 dengan kelompok kontrol. Sebelum mengetahui berapa besar keefektifan antara kedua kelompok tersebut, makan dilakukan terlebih dahulu uji anava untuk membuktikan ada atau tidaknya perbedaan keefektifan antara ketiga kelompok. Uji anava pada ketiga kelompok, dapat diliht pada tabel 5 .

Berdasarkan hasil anava pada tabel 1 , diperoleh nilai $\mathrm{F}$ sebesar 15.328 dan nilai sig. $\leq$ $0,05(5 \%)$. Berdasarkan hasil tersebut hipotesis nihil $\left(\mathrm{H}_{\mathrm{O}}\right)$ ditolak, dan dari hasil nilai signifikansi yang diperoleh dapat diambil kesimpulan bahwa pada kelompok eksperimen 1, eksperimen 2, dan kelompok kontrol memiliki perbedaan keefektifan. Selain melihat hasil analisis varian satu jalan untuk mengetahui ada atau tidaknya perbedaan pada kelompok yang dibandingkan, pada penelitian ini juga dilanjutkan dengan Uji Scheffe. Uji Scheffe dilakukan untuk melihat seberapa besar perbedaan keefektifan antara

Tabel 5. Hasil Uji Beda dengan Menggunakan Analisis Anava Satu Jalur Menggunakan Program SPSS 21

\begin{tabular}{lccccc}
\multicolumn{5}{c}{ ANOVA } \\
Post Test \\
\hline Sum of Squares & Df & Mean Square & F & Sig. \\
\hline Between Groups & 2580,933 & 2 & 1290,467 & 15,328 &, 000 \\
Within Groups & 8587,200 & 102 & 84,188 & & \\
\hline Total & 11168,133 & 104 & & & \\
\hline
\end{tabular}

Keefektifan Teknik DIE dan Teknik Objek Langsung dalam Keterampilan ... (Sawacu Pragina) 
Tabel 6. Hasil Uji Scheffe Test Satu Jalur Kelompok Eksperimen 1 dengan Kelompok Kontrol

\begin{tabular}{cccccc}
\hline Scheffe & & & & & \\
\hline $\begin{array}{c}\text { Dependent } \\
\text { variable }\end{array}$ & $(\mathrm{I})$ & $(\mathrm{J})$ & Mean Different & Std. error & Sig. \\
\hline Postes & $\begin{array}{c}\text { Kelompok } \\
\text { eksperimen 1 }\end{array}$ & Kelompok kontrol & $12.14286^{*}$ & 2.19334 & .000 \\
\hline
\end{tabular}

Tabel 7. Hasil Uji Scheffe Test Satu Jalur Kelompok Eksperimen 2 dengan Kelompok Kontrol

\begin{tabular}{cccccc}
\hline Scheffe & & & & & \\
\hline $\begin{array}{c}\text { Dependent } \\
\text { variable }\end{array}$ & $(\mathrm{I})$ & $(\mathrm{J})$ & Mean Different & Std. error & Sig. \\
\hline Postes & $\begin{array}{c}\text { Kelompok } \\
\text { eksperimen 2 }\end{array}$ & Kelompok kontrol & $5.91429^{*}$ & 2.19334 & .030 \\
\hline
\end{tabular}

Tabel 8. Hasil Uji Scheffe Test Satu Jalur Kelompok Eksperimen 1 dengan Kelompok Eksperimen 2

\begin{tabular}{cccccc}
\hline Scheffe & & & & & \\
\hline $\begin{array}{c}\text { Dependent } \\
\text { variable }\end{array}$ & $(\mathrm{I})$ & $(\mathrm{J})$ & Mean Different & Std. error & Sig. \\
\hline Postes & $\begin{array}{c}\text { Kelompok } \\
\text { eksperimen 1 }\end{array}$ & $\begin{array}{c}\text { Kelompok } \\
\text { eksperimen 2 }\end{array}$ & $6.22857^{*}$ & 2.19334 & .021 \\
\hline
\end{tabular}

kelompok eksperimen maupun kelompok kontrol atau dengan kata lain untuk melihat teknik mana yang lebih efektif pada kelompok yang dibandingkan. Pada uji hipotesis yang pertama ini, kelompok eksperimen 1 dan kelompok kontrol akan diuji dengan uji Scheffe menggunakan program SPSS versi 21,0. Hasil uji Scheffe dijelaskan pada tabel 6 .

Berdasarkan tabel 6, diperoleh nilai sig. $\leq 0,05(5 \%)$ artinya terdapat perbedaan keefektifan antara kelompok eksperimen 1 dan kelompok kontrol. Oleh karena itu, hipotesis nihil $\mathrm{H}_{0}$ yang menyatakan "Tidak terdapat perbedaan hasil belajar bercerita dengan alat peraga pada siswa antara kelompok yang menggunakan teknik DIE dengan kelompok yang menggunakan teknik konvensioanl ditolak dan $\mathrm{H}_{1}$ diterima. Selain itu, perbedaan nilai rata-rata antara penggunaan teknik DIE pada kelompok eksperimen 1 dan yang menggunakan teknik konvensional pada kelompok kontrol adalah 12.14286 yang berarti bahwa penggunaan teknik DIE pada kelompok eksperimen 1 lebih efektif jika dibandingkan dengan kelompok kontrol.

Pada uji hipotesis yang kedua, akan diuji menggunakan uji Scheffe untuk mengetahui seberapa besar perbedaan keefektifan antara kelompok eksperimen kedua dengan kelompok kontrol. Hasil uji Scheffe dapat dilihat pada tabel 7.
Berdasarkan tabel 7, diperoleh nilai sig. $\leq 0,05(5 \%)$ artinya terdapat perbedaan keefektifan antara kelompok eksperimen 2 dan kelompok kontrol. Oleh karena itu, hipotesis nihil $\mathrm{H}_{0}$ yang menyatakan "Tidak terdapat perbedaan hasil belajar bercerita dengan alat peraga pada siswa antara kelompok yang menggunakan teknik Objek Langsung dengan kelompok yang menggunakan teknik konvensional" ditolak dan $\mathrm{H}_{1}$ diterima. Selain itu, perbedaan nilai rata-rata antara penggunaan teknik Objek Langsung pada kelompok eksperimen 2 dan yang menggunakan teknik konvensional pada kelompok kontrol adalah 5.91429 yang berarti bahwa penggunaan teknik Objek Langsung pada kelompok eksperimen 2 lebih efektif jika dibandingkan dengan kelompok kontrol yang menggunakan teknik konvensional.

Pada uji hipotesis yang ketiga, akan diuji juga menggunakan uji Scheffe untuk mengetahui seberapa besar perbedaan keefektifan antara kelompok eksperimen pertama dengan kelompok eksperimen kedua. Hasil uji Scheffe dapat dilihat pada tabel 8.

Berdasarkan tabel 8, diperoleh nilai sig. $\leq 0,05(5 \%)$ artinya terdapat perbedaan keefektifan antara kelompok eksperimen 1 dan kelompok eksperimen 2. Oleh karena itu, diambil kesimpulan bahwa hipotesis nihil $\mathrm{H}_{0}$ 
yang menyatakan "Tidak terdapat perbedaan hasil belajar bercerita dengan alat peraga pada kelompok siswa yang menggunakan teknik DIE dengan kelompok yang menggunakan teknik Objek Langsung." ditolak dan $\mathrm{H}_{1}$ diterima. Selain itu, perbedaan nilai rata-rata antara penggunaan teknik DIE pada kelompok eksperimen 1 yaitu di Kelompok A dan pada penggunaan teknik Objek Langsung pada kelompok eksperimen 2 yaitu di Kelompok $C$ diperoleh perbedaan sebesar 6.22857 yang berarti bahwa penggunaan teknik DIE pada kelompok eksperimen 1 yaitu di Kelompok A lebih efektif jika dibandingkan dengan penggunaan teknik Objek Langsung pada kelompok eksperimen 2 yaitu di Kelompok C. Berdasarkan semua hasil uji hipotesis dengan menggunakan Anava dan uji Scheffe pada program SPSS versi 21,0 baik pada dua kelompok eksperimen dan kelompok kontrol dapat disimpulkan bahwa penggunaan teknik DIE pada kelompok eksperimen 1 merupakan teknik yang paling efektif dalam pembelajaran bercerita dengan alat peraga.

Berdasarkan uji hipotesis, diperoleh hasil penelitian yang meliputi: (1) teknik DIE efektif digunakan dalam pembelajaran keterampilan bercerita dengan alat peraga pada siswa kelas VII SMP Plus Munirul Arifin NW Praya Kabupaten Lombok Tengah; (2) teknik Objek Langsung efektif digunakan dalam pembelajaran keterampilan bercerita dengan alat peraga pada siswa kelas VII SMP Plus Munirul Arifin NW Praya Kabupaten Lombok Tengah; (3) teknik DIE lebih efektif dibandingkan dengan teknik Objek Langsung dalam pembelajaran keterampilan bercerita dengan alat peraga pada siswa kelas VII SMP Plus Munirul Arifin NW Praya Kabupaten Lombok Tengah.

Hasil penelitian yang pertama yang menunjukan bahwa teknik DIE efektif digunakan dalam pembelajaran bercerita dengan alat peraga pada siswa kelas VII SMP Plus Munirul Arifin NW Praya Kabupaten Lombok Tengah karena pada penerapannya Teknik DIE dapat dimanfaatkan sebagai teknik pembelajaran pada materi keterampilan berbicara khususnya pada keterampilan bercerita dengan alat peraga. Abidin (2013) menjelaskan bahwa keterampilan berbicara menempati kedudukan yang sangat penting bagi siswa karena merupakan ciri dari kemampuan komunikatif siswa. Dengan kata lain, bercerita sebagai bagian dari keterampilan berbicara merupakan salah satu keterampilan yang dapat menunjukkan kemampuan komunikatif siswa serta erat kaitannya dengan kegiatan memproduksi ide. Ide yang dimaksud adalah buah pikiran yang dihasilkan pembicara atau pencerita dari pengamatan, pengalaman dan imajinasi. Segala bentuk buah pikiran yang dihasilkan dari pengamatan, pengalaman maupun imajinasi dapat dilakukan dengan memanfaatkan teknik DIE yang menggunakan media gambar sebagai sumber pengamatan dan imajinasi sesuai dengan kebutuhan situasi dan kondisi pencerita.

Peran teknik DIE dalam tahap persiapan menyusun pokok-pokok cerita dan bercerita menyampaikan isi cerita, meliputi (1) siswa memiliki kebebasan untuk meningkatkan pengetahuan yang mereka miliki melalui teknik pembelajaran yang dilakukan secara kelompok, (2) siswa mampu menyusun pokok-pokok cerita secara singkat dan jelas berdasarkan gambar yang dianalisis secara cermat dan kemudian mampu menyusun pokok-pokok cerita tersebut menjadi cerita yang menarik dengan mengikuti langkah kerja dari teknik DIE yaitu mendeskripsikan apa yang terdapat di dalam gambar, menginterpretasi dan kemudian mengevaluasi nilai-nilai yang ada di dalam gambar, (3) imajinasi siswa terstimulasi dengan baik karena didukung oleh media gambar yang menarik dengan variasi tema yang telah ditentukan (4) materi pembelajaran bercerita dengan alat peraga terlihat sederhana bagi para pendengar cerita karena dijabarkan dengan kreatif, dan (5) menjadikan pendengar cerita menjadi berpatisipati aktif baik ketika berperan sebagai pendengar aupun penilai bagi teman yang lain dalam kegiatan bercerita dengan alat peraga.

Pemanfaatan teknik DIE sebagai teknik dalam pelajaran bercerita dengan alat peraga dapat memudahkan pencerita atau siswa untuk mengidentifikasi segala ide dan gagasan secara runtut dan terkonsep dari gambar yang diberikan sebelum performansi. Selanjutanya teknik DIE dapat diwujudkan menjadi teknik pembelajaran bercerita dengan alat peraga yang mudah untuk dibuat dan disusun. Dalam teknik tersebut terdapat beberapa pertanyaan-pertanyaan yang terkait 
dengan gambar seperti pertanyaan pertama yaitu deskripisi (apakah yang dilihat pada gambar?), pertanyaan kedua yaitu interpretasi (apakah yang dipikirkan tentang apa yang dilihat?) dan pertanyaan ketiga yaitu evaluasi (apakah yang dirasakan tentang apa yang dipikirkan?). Beberapa pertanyaan tersebut mampu memunculkan ide maupun gagasan siswa berdasarkan wawasan siswa. Ide dan gagasan yang telah teridentifikasi kemudian dijadikan siswa sebagai poin penting untuk menyusun pokok-pokok cerita menjadi sebuah cerita yang menarik yang disampaikan melalui pembelajaran bercerita dengan alat peraga.

Salah satu indikator ketercapaian peserta didik siswa Kelompok VII SMP pada materi bercerita denga alat peraga adalah mampu merangkai pokok-pokok cerita menjadi sebuah cerita yang menarik kemudian menyampaikan isi cerita secara lisan melalui kegiatan bercerita dengan alat peraga dan memperhatikan aspekaspek penilaian seperti pelafalan, ekspresi (mimik muka dan gerakan badan), ketepatan logika isi cerita, struktur, ketepatan pilihan kata, dan kelancaran. Berdasarkan hal tersebut, DIE sebagai teknik pembelajaran dapat disesuaikan dengan indikator ketercapaian pada materi pembelajaran bercerita dengan alat peraga.

Berdasarkan uraian di atas, penggunaan teknik DIE sebagai teknik pembelajaran bercerita dengan alat peraga sesuai digunakan. Teknik DIE dapat membantu siswa untuk mempersiapkan dan mengidentifikasi ide dan gagasan secara kreatif untut kemudian disampaikan secara runtut, lengkap dan jelas. Selanjutnya, seberapa efektifkah teknik DIE apabila digunakan dalam pembelajaran bercerita dengan alat peraga dibandingkan dengan teknik konvensional yang biasa digunakan oleh guru akan diuraikan berdasarkan hasil statistik sebagai berikut.

Berdasarkan hasil uji Anava yang dilanjutkan dengan uji Scheffe mengenai keefektifan teknik DIE dibandingkan dengan teknik konvensional yang digunakan oleh guru terhadap keterampilan bercerita dengan alat peraga pada siswa kelompok VII SMP Plus Munirul Arifin Praya Kabupaten Lombok Tengah menunjukkan nilai signifikansi untuk kelompok eksperimen 1 yang menggunakan teknik DIE dan kelompok kontrol yang menggunakan teknik konvensional $\leq 0,05(5 \%)$, sehingga diambil kesimpulan bahwa terdapat perbedaan keefektifan antara kelompok yang menggunakan teknik DIE dan kelompok kontrol yang menggunakan teknik konvensional. Hipotesis nihil $\mathrm{H}_{0}$ yang menyatakan "Tidak terdapat perbedaan hasil belajar bercerita dengan alat peraga pada kelompok siswa yang menggunakan teknik DIE dengan kelompok siswa yang menggunakan teknik konvensional" ditolak dan $\mathrm{H}_{1}$ diterima. Selain itu, kita juga dapat melihat perbedaan pada nilai rata-rata antara penggunaan teknik DIE pada kelompok eksperimen 1 yang memperoleh rata-rata sebesar 79.6571 dan yang menggunakan teknik konvensional pada kelompok kontrol mendapat nilai rata-rata sebesar 67.5143. Perbedaan nilai rata-rata antara dua kelompok tersebut adalah 12.14286 yang berarti bahwa penggunaan teknik DIE pada kelompok eksperimen 1 lebih efektif jika dibandingkan dengan kelompok kontrol yang menggunakan konvensional.

Pembahasan penelitian untuk uji hipotesis kedua yang menyatakan bahwa teknik objek langsung efektif digunakan dalam keterampilan bercerita dengan alat peraga pada siswa kelas VII SMP Plus Munirul Arifin NW Praya Kabupaten Lombok Tengah terbukti karena Teknik Objek Langsung melalui teknik pembelajaran kontekstual komponen pemodelan merupakan salah satu teknik yang mampu memberikan stimulasi efektif pada siswa dalam berbagai keterampilan berbahasa terutama pada keterampilan menulis. Akan tetapi, jika melihat keterampilan berbahasa yang lain, teknik ini juga dapat menjadi stimulasi bagi siswa dalam membangun inovasi dan semangat belajar khususnya pada keterampilan berbicara yaitu bercerita dengan alat peraga.

Penerapan teknik Objek Langsung dalam pembelajaran bercerita dengan alat peraga yaitu guru atau peneliti menampilkan teknik atau objek secara langsung kepada siswa di dalam maupun di luar kelompok. Objek yang ditampilkan dapat berupa objek yang berupa benda, situasi maupun kondisi yang ada di sekitar. Objek yang berupa benda, dapat guru tampilkan secara langsung di dalam kelompok misalnya dengan memberikan siswa contoh benda-benda yang tidak berbahaya, seperti; boneka, alat-alat tulis, patung-patung bersejarah 
yang berkaitan dengan sejarah Indoneia, dll. Benda-benda yang dijadikan sebagai Objek Langsung tersebut kemudian dijadikan siswa sebagai stimulasi untuk merangkai pokok-pokok cerita berdasarkan benda yang mereka amati dan tentunya berdasarkan tema bercerita yang telah ditentukan oleh guru. Kegiatan merangkai pokok-pokok cerita tersebut kemudian disusun menjadi sebuah cerita yang menarik dan disampaikan dalam pembelajaran bercerita dengan alat peraga. Objek yang berupa situasi maupun kondisi yang ada di sekitar dapat berupa suatu keadaan atau situasi yang secara langsung dapat dilihat oleh siswa. Salah satu contoh objek yang berupa situasi dan kondisi yang ada di sekitar misalnya ketika pembelajaran bercerita dengan alat peraga dengan tema kebersihan, siswa dapat melihat objek langsung berupa kolam kotor yang ada di lingkungan sekolah sebagai stimulasi untuk siswa dalam menyusun pokok-pokok cerita menjadi sebuah cerita yang menarik kemudian diceritakan dalam kegiatan pembelajaran bercerita dengan alat peraga. Proses belajar bercerita pun berlangsung menyenangkan dan penuh kebermaknaan karena siswa akan dengan mudah dapat memikirkan gagasan, ide, maupun pendapatnya terhadap objek langsung yang diamati.

Pada penerapan teknik Objek Langsung dalam kegiatan bercerita dengan alat peraga, yang paling perlu diperhatikan adalah pemilihan objek langsung yang sesuai dengan tema kegiatan bercerita dan ditentukan oleh seorang guru atau peneliti sesuai dengan keadaan di sekitar dan kebutuhan siswa. Guru atau peneliti diharapkan dapat menentukan tema secara cermat. Hal tersebut menjadi penting karena objek langsung yang dijadikan stimulasi bagi siswa dalam menyusun pokok-pokok cerita harus dipersiapkan secara matang dan baik oleh guru atau peneliti yang menerapkan teknik ini.

Penerapan teknik Objek Langsung dalam pembelajaran bercerita dengan alat peraga dapat memudahkan siswa untuk mengikuti pelajaran dengan aktif. Hal tersebut karena pembelajaran kontekstual menekankan pada pentingnya diciptakan suatu lingkungan yang alamiah dalam proses belajar dengan tujuan para siswa mengalami sendiri apa yang dipelajarinya sehingga proses pembelajaran menjadi jauh lebih bermakna (Nurhadi, 2009). Para siswa dalam penerapan teknik Objek Langsung dalam kegiatan bercerita dengan alat peraga aktif melakukan kerja sama dengan kelompoknya dalam memecahkan masalah yang ditemukan dalam pengamatan Objek Langsung yang dijadikan sebagai cerita yang menarik berdasarkan pokok-pokok cerita yang dirangkai bersama dan disampaikan dalam kegiatan bercerita dengan alat peraga. Teknik Objek Langsung dengan pembelajaran kontekstual seperti ini tentunya membuat kegiatan pembelajaran menjadi lebih produktif dan bermakna bagi siswa karena setiap indera yang dimiliki oleh anak bergerak aktif dibandingkan siswa hanya mendengarkan guru menjelaskan.

Berdasarkan uraian tersebut, penggunaan teknik Objek Langsung dalam pembelajaran bercerita dengan alat peraga dapat memotivasi dan memberikan stimulasi yang baik pada siswa dalam menyusun dan kemudian menyampaikan cerita yang disusun dalam kegiatan bercerita dengan alat peraga. Teknik Objek Langsung terbukti efektif tidak hanya dalam pembelajaran menulis deskripsi dalam keterampilan menulis, namun teknik ini dapat juga menjadi efektif dalam keterampilan berbicara khususnya dalam bercerita dengan alat peraga. Selanjutnya, seberapa efektifkah teknik Objek Langsung apabila digunakan dalam pembelajaran bercerita dengan alat peraga dibandingkan dengan teknik pembelajaran konvensional yang biasanya digunakan oleh guru akan diuaraikan berdasarkan hasil statistik sebagai berikut.

Berdasarkan hasil uji Anava yang dilanjutkan dengan uji Scheffe menggunakan program SPSS versi 21,0 diperoleh nilai signifikansi untuk kelompok eksperimen 2 yang menggunakan teknik Objek Langsung dan kelompok kontrol yang menggunakan teknik konvensional $\leq 0,05$ $(5 \%)$, sehingga diambil kesimpulan bahwa terdapat perbedaan keefektifan antara siswa yang menggunakan teknik Objek Langsung pada kelompok eksperimen 2 dengan siswa yang menggunakan teknik konvensional pada kelompok kontrol. Hipotesis nihil $\mathrm{H}_{0}$ yang menyatakan "Tidak terdapat perbedaan hasil belajar bercerita dengan alat peraga siswa antara kelompok yang menggunakan teknik Objek Langsung dengan kelompok yang menggunakan teknik konven- 
sional" ditolak dan $\mathrm{H}_{1}$ diterima. Selain itu, perbedaan nilai rata-rata antara penggunaan teknik Objek Langsung pada Kelompok eksperimen 2 sebesar 73.4286 dan yang menggunakan teknik konvensional pada kelompok kontrol memiliki nilai rata-rata sebesar 67.5143 dengan perbedaan rata-rata yang diperoleh yaitu 5.91429. Berdasarkan hal tersebut diambil kesimpulan bahwa penggunaan teknik Objek Langsung pada kelompok eksperimen 2 lebih efektif jika dibandingkan dengan kelompok kontrol yang menggunakan teknik konvensional.

Selanjutnya, pada uji hipotesis yang ketiga yang menyatakan bahwa teknik DIE lebih efektif dibandingkan teknik Objek Langsung dalam keterampilan bercerita dengan alat peraga pada siswa kelas VII SMP Plus Munirul Arifin NW Praya Kabupaten Lombok Tengah. Pada pembahasan penelitian ini, hal yang perlu ditegaskan bahwa setelah dilakukan uji hipotesis menggunakan uji Anava satu jalur untuk mengetahui ada atau tidaknya perbedaan keefektifan yang dilanjtutkan uji Scheffe untuk mengetahui seberapa besar perbedaan keefektifan khususnya untuk penggunaan teknik DIE dan teknik Objek Langsung diperoleh hasil bahwa teknik DIE lebih efektif dibandingkan teknik Objek Langsung dalam pembelajaran bercerita dengan alat peraga pada siswa SMP Plus Munirul Arifin NW Praya Kabupaten Lombok Tengah.

Uraian di atas dibuktikan berdasarkan hasil uji Anava yang dilanjutkan dengan uji Scheffe untuk kelompok eksperimen 1 yang menggunakan teknik DIE dan kelompok eksperimen 2 yang menggunakan teknik Objek Langsung terdapat perbedaan dengan nilai sig. $\leq 0,05$ (5\%). Selanjutnya, untuk hasil uji Scheffe antara kelompok eksperimen 1 dan kelompok eksperimen 2 diperoleh perbedaan keefektifan sebesar 6.22857 dengan nilai rata-rata eksperimen 1 sebesar 79.6571 sedangkan nilai rata-rata eksperimen 2 sebesar 73.4286 yang berarti bahwa penggunaan teknik DIE pada kelompok eksperimen 1 yaitu di Kelompok A lebih efektif jika dibandingkan dengan penggunaan teknik Objek Langsung pada kelompok eksperimen 2 yaitu di Kelompok C. Berdasarkan perhitungan statistik atau tepatnya dari hasil uji hipotesis yang telah dilakukan dapat disimpulkan bahwa teknik DIE merupakan teknik yang paling efek- tif dalam keterampilan bercerita dengan alat peraga pada siswa kelas VII SMP Plus Munirul Arifin NW Praya Kabupaten Lombok Tengah Provinsi Nusa Tenggara Barat.

\section{SIMPULAN}

Berdasarkan hasil uji hipotesis dan pembahasan yang telah dipaparkan pada bab IV, dapat diambil kesimpulan sebagai jawaban akhir atas permasalahan penelitian, yaitu sebagai berikut; (1) ada perbedaan keefektifan antara penggunaan teknik DIE dan teknik konvensional dalam keterampilan bercerita dengan alat peraga pada siswa Kelompok VII SMP Plus Munirul Arifin NW Praya Kabupaten Lombok Tengah. Perbedaan tersebut membuktikan teknik DIE lebih efektif dibandingkan teknik Konvensional. Hal ini dibuktikan oleh uji Scheffe menggunakan program SPSS versi 21,0 dengan nilai sig. $\leq 0,05$; (2) ada perbedaan keefektifan antara penggunaan teknik Objek Langsung dan teknik konvensional dalam keterampilan bercerita dengan alat peraga pada siswa Kelompok VII SMP Plus Munirul Arifin NW PrayaKabupaten Lombok Tengah. Perbedaan tersebut membuktikan teknik Objek Langsung lebih efektif dibandingkan teknik Konvensional. Hal ini dibuktikan oleh uji Scheffe menggunakan program SPSS versi 21,0 dengan nilai sig. $\leq 0,05$; (3) teknik DIE lebih efektif dibandingkan teknik Objek Langsung dalam keterampilan bercerita dengan alat peraga pada siswa Kelompok VII SMP Plus Munirul Arifin NW Praya Kabupaten Lombok Tengah. Perbandingan keefektifan tersebut membuktikan bahwa teknik DIE merupakan teknik yang paling efektif dalam keterampilan bercerita dengan alat peraga. Keefektifan teknik DIE tersebut dibuktikan oleh uji Scheffe dengan nilai dengan nilai sig. $\leq 0,05$.

\section{Saran}

Berdasarkan simpulan, dapat disarankan beberapa hal sebagai berikut, teknik DIE yang merupakan teknik pembelajaran yang paling efektif dibandingkan dengan dua teknik yaitu teknik objek langsung dan teknik konvensional yang digunakan guru sebaiknya digunakan sebagai salah satu teknik pembelajaran yang digunakan oleh guru untuk meningkatkan keterampilan berbicara khususnya dalam pem- 
belajaran bercerita dengan alat peraga pada siswa kelas VII di SMP Plus Munirul Arifin NW Praya Kabupaten Lombok Tengah. Teknik pembelajaran ini efektif karena melibatkan siswa berpatisipasi aktif dan kreatif baik secara individual maupun secara berkelompok. Siswa pada akhirnya mengalami proses pembelajaran yang bermakna. Guru mata pelajaran bahasa Indonesia kelas VII di SMP Plus Munirul Arifin NW Praya kabupaten Lombok Tengah disarankan menggunakan stimulasi media gambar dari teknik DIE menggunakan gambar yang sesuai dengan tema yang akan dibahas dalam proses pembelajaran bercerita dengan alat peraga. Hal tersebut dilakukan dengan tujuan aga siswa mampu mengeksplorasi pengetahuan yang dimiliki sehingga tujuan berbicara siswa yaitu meningkatkan kemampuan linguistik maupun paralinguistik berkembang dengan baik. Selanjutnya untuk penggunaan media yang menarik dan inovatif perlu ditambah keberadaannya dalam suatu sekolah dikarenakan hal ini sangat berpengaruh sebagai stimulus terhadap keterampilan berbicara siswa khusunya dalam bercerita dengan alat peraga. Penggunaan media yang menarik akan banyak membantu siswa secara kreatif untuk mengembangkan kemampuan mereka dalam menyusun pokok-pokok cerita yang disusun menjadi sebuah cerita menarik dan disampaikan kepada para pendengar cerita melalui proses bercerita baik di dalam maupun di luar kelas.

\section{DAFTAR PUSTAKA}

Ismawati, E. 2009. Metode penelitian pendidikan bahasa \& sastra. Yogyakarta: Cawanmas.

Musfiroh, T. 2008. Memilih, menyusun dan menyajikan cerita untuk anak usia dini. Yogyakarta: Tiara Wacana.

Nurgiyantoro, B. 2013. Penilaian pembelajaran bahasa. Yogyakarta: BPFE-YOGYAKARTA.

Nurhadi \& Senduk, A.G. 2009. Pembelajaran kontekstual. Surabaya: PT.Jepe Press Media Utama.

Sudjana, H.D. 2001. Metode dan teknik pembelajaran partisipatif. Bandung: Falah Production.

Suyatno. 2004. Teknik pembelajaran bahasa dan sastra. Surabaya: Penerbit SIC.

Tompkins, G.E., \& Hoskisson, K. 1995. Language arts content and teaching strategies. United States of Amerika: Prentice-Hall, Inc.

Thomas, L \& Wareing, S. 2007. Bahasa, masyarakat, \& kekuasaan. Yogyakarta: PUSTAKA BELAJAR. 